Milica Jaramaz ${ }^{l}$

UDK : 374.7 (497.16)

\title{
BARIJERE PARTICIPACIJE U OBRAZOVANJU ODRASLIH U CRNOJ GORI ${ }^{2}$
}

\begin{abstract}
- Sažetak -
U savremenom svijetu učenje i obrazovanje su način čovjekovog opstanka $i$ društvenog $i$ individualnog razvoja. Svjedoci smo da svakoga dana sve više narastaju obrazovne potrebe pojedinaca, tj. zaposlenje, napredovanje u profesiji, promjena ili zadržavanje radnog mjesta iziskuju uključivanje $u$ proces učenja $i$ obrazovanja. Poznato je da proces participacije odraslih u programima obrazovanja prate brojne barijere, a ishod toga je izrazito niska stopa participacije u Crnoj Gori, kao i u zemljama u regionu. Prema tome, ovaj rad je usmjeren na sagledavanje ključnih barijera u obrazovanju odraslih, zapravo cilj istraživanja se odnosio na utvrđivanje hijerarhije barijera $i$ utvrđivanje povezanosti između seta socijalno-demografskih obilježja i barijera obrazovanja kao i nivoa obrazovnog osujećenja.
\end{abstract}

Ključne riječi: obrazovanje odraslih, barijere obrazovanja, participacija.

\section{Teorijski okvir}

Participacija odraslih u učenju i obrazovanju je izuzetno kompleksan socijalno-psihološki fenomen, koji zaokuplja pažnju savremene naučne i stručne javnosti. Kada se raspravljava o obrazovanju i učenju odraslih, onda je skoro nezaobilazna analiza participacije odraslih u programima obrazovanja, jer je upravo ovo tema o kojoj se sve više govori, diskutuje, istražuje i koja se analizira. Naime, za područje obrazovanja odraslih neizmjerno je važno baviti se participacijom, tj. motivima i barijerama obrazovanja.

1 Mr. Milica Jaramaz, magistar pedagogije, saradnik u nastavi na Filozofskom fakultetu u Nikšiću, Univerzitet Crne Gore, Studijski program za pedagogiju.

2 Izvod iz magistarskog rada. 
Budući da nije jednostavno odgovoriti na pitanje zašto se odrasli uključuju u obrazovne aktivnosti, nije lako doći ni do odgovora zašto se odrasli ne uključuju u obrazovne aktivnosti. Stoga je uočavanje, sagledavanje i analiza barijera participacije jako važna kako bi se mogli pronaći putevi za njihovo prevazilaženje. Spoznaja ključnih barijera i njihovo razumijevanje i savladavanje obezbijediće nesmetano zadovoljavanje obrazovnih potreba pojedinaca. Upravo iz ovih razloga, kako pokazuju komparativna istraživanja, u andragogiji su često proučavane barijere participacije. Pored toga što se fenomen participacije odraslih u programima obrazovanja često istražuje mišljenja smo da ne gubi na aktuelnosti, jer je participacija uvijek uslovljena socijalnim kontekstom, tj. sredinom u kojoj se ostvaruje. Samim tim primjećujemo veliku raznorodnost kada su u pitanju barijere participacije, jer svaka sredina ima svoje specifičnosti i od brojnih faktora zavisi da li je određeni socijalni kontekst stimulišući ili destimulišući kada je u pitanju uključivanje odraslih u obrazovne aktivnosti.

Različita istraživanja ometajućih faktora procesa participacije, odnosno osujećenja tog procesa, utvrdila su postojanje brojnih barijera u obrazovanju odraslih. Jedno od najznačajnijih istraživanja je autorke Cross, koja je barijere participacije odraslih $\mathrm{u}$ obrazovanju klasifikovala $\mathrm{u}$ tri grupe: situacione, institucionalne i dispozicione (Kulić, Despotović, 2005: 164165). Ova klasifikacija je jedna od najranijih i poslužila je kao osnova za dalja istraživanja ovog problema. Svakako, bilo je značajno osvrnuti se na rezultate brojnih studija, a među njima izdvajamo rezultate istraživanja koje je poduzeto u Finskoj. ${ }^{3}$ Barijere participacije u obukama koje plaćaju poslodavci su: nedostatak vremena zbog previše obaveza na poslu; poslodavac ne nudi obuku; nedostatak odgovarajuće obuke; teškoće prilikom uključivanja u obuku; poslodavac ne vrednuje obuku; nedostatak informacija o mogućnostima; nedostatak beneficija od same obuke; nizak nivo kvaliteta obuke; nezainteresovanost; strah od neuspjeha; finansijske poteškoće; ostale prepreke. Osim ovih, istim istraživanjem ispitane su i barijere participacije odraslih u obrazovanju tokom slobodnog vremena i o trošku participanta. Na vrhu hijerarhije barijera participacije obrazovanja odraslih tokom slobodnog vremena i o trošku participanta su finansijski razlozi. Zatim, lokacija obuke, umor, nezainteresovanost, neprikladno radno vrijeme, nedostatak odgovarajućih obrazovnih programa, nedostatak benefita od obuke, nedovoljno osnovno obrazovanje, nedostatak informacija o mogućnostima, godine starosti i zdravstveno stanje, zadovoljenje drugih potreba u slobodnom

3 www.stat.fi/til/aku/1995. Dostupno: [19. 5. 2012.]. 
vremenu, problemi u odgajanju djeteta, slab kvalitet obuke, kućni i porodični razlozi, strah od neuspjeha i ostale prepreke.

Koliko je značajan nedostatak novca kao faktor osujećenja participacije u obrazovanju upravo nam pokazuju prethodno pomenuti rezultati, jer u hijerarhiji barijera obrazovanja koje plaća poslodavac zauzima posljednje mjesto, dok u hijerarhiji barijera gdje pojedinac sam snosi troškove obrazovanja zauzima prvo mjesto.

Carp, Peterson i Roelfs su analizirali aktivnosti učenja odraslih koji su već uključeni u učenje. Oni su prema važnosti istakli sljedeće barijere: troškovi, nedovoljno vremena, nedovoljno želje da se škola pohađa sve vrijeme, porodične odgovornosti, odgovornosti na poslu i količina vremena koja je potrebna da bi se završio program (Kulić, 1997: 112). Dakle, rezultati i ovog istraživanja upravo pokazuju da u hijerarhiji barijera primat zauzimaju nedostatak novca i nedostatak vremena. To nam govori da su čovjekovi egzistencijalni problemi ključni razlozi njegove neparticipacije u obrazovnim aktivnostima.

Shipp i McKenzie koristeći faktorsku anlizu otkrili su sljedeće faktore neparticipacije: odupiranje promjeni i obrazovanju, otuđenje, marginalizovanost, nedruželjubivost, nerelevantnost programa. ${ }^{4}$ Uočavamo da je ova klasifikacija barijera drugačija u odnosu na prethodne. Zapravo, ovdje su više opisane barijere, koje su u vezi sa ličnošću participanata, i koje zavise od njegovih stavova, percepcije i odnosa prema obrazovanju i okruženju. Osim toga, rezultati istraživanja u velikoj mjeri zavise od socijalnog konteksta kome ispitanici pripadaju. Budući da čovjekovo okruženje, sredina u kojoj živi determiniše participaciju u obrazovanju, na isti način determiniše i neparticipaciju.

I naši autori su se bavili problemom barijera participacije odraslih u obrazovanju i učenju. Stoga smatramo da je važno pomenuti i rezultate istraživanja prof. Savićevića. Rezultati pokazuju da se na vrhu rang-liste barijera kod ispitivanih muškaraca i žena nalaze nedostatak vremena i nedostatak novca. Treće mjesto zauzima nemanje mogućnosti da se ispitanici obrazuju u sredini u kojoj žive. Ostale barijere se odnose na percepciju ličnosti i mogućnosti ispunjavanja obrazovnih zadataka: nedostatak energije, obrazovanje ne pričinjava zadovoljstvo, slabi rezultati postignuti u prethodnom obrazovanju, stavovi pojedinca u vezi sa godinama koje smatraju pogodnim za učenje...(Savićević, 1989: 211-212).

4 Vidi: Malhotra, N., Sizoo, S., Chorvat, V. (1999): Barriers to adult participation in undergraduate education, „Adult Higer Education Alliance,,. Dostupno na: www.ahea.org/files/pro1999malhotra. pdf [20. 5. 2012.]. 
Osvrćući se na rezultate prethodnih istraživanja uviđamo da su barijere participacije odraslih u obrazovnim aktivnostima zaista raznorodne. Ono što se izdvaja $u$ većini istraživanja je činjenica da su nedostatak novca i nedostatak vremena ključni faktori osujećenja čovjekove participacije u učenju i obrazovanju. Pored toga što situacione barijere zauzimaju primat, nijedna zajednica ne bi trebalo da zanemaruje institucionalne i dispozicione barijere. Smatramo da svako društvo, kompanije, i pojedinci treba najprije da otkriju i identifikuju barijere, a zatim da pristupe sistematskom otklanjanju istih. Kako smo i ranije istakli, participacija odraslih u obrazovanju zavisi od samog pojedinca, zatim od materijalno-tehničkih uslova, odnosno postojanja objektivnih mogućnosti i od socijalnog konteksta. Upravo barijere participacije treba analizirati na navedenim nivoima $i$ raditi na njihovom savladavanju. Ovo dobija na važnosti ako se ima u vidu činjenica da su učenje i obrazovanje ključ razvoja svakog pojedinca i društva u cjelini.

\section{Cilj istraživanja}

Participacija, kao proces zadovoljavanja obrazovnih potreba, utiče na poboljšanje i dobijanje većih kompetencija, povećava zapošljivost i mobilnost na savremenom tržištu rada, kao i ostvarivanje socijalne inkluzije. Kako smo već isticali, smatramo da je vrlo značajno da svako društvo odnosno lokalna zajednica identifikuje glavne barijere participacije odraslih u obrazovanju. Njihova identifikacija i savladavanje nesumnjivo utiče na povećanje stope participacije, koja je izrazito niska u Crnoj Gori kao i u zemljama u regionu. Polazeći od prethodnih istraživanja opredijelili smo se da cilj istraživanja odredimo dvostruko:

- utvrditi hijerarhiju barijera odraslih za učenje;

- utvrditi da li socijalno-demografska obilježja determinišu barijere obrazovanja i nivo obrazovnog osujećenja.

Imajući u vidu prethodno formulisan cilj, hipoteze našeg istraživanja definisali smo na sljedeći način:

- pretpostavlja se da su na vrhu hijerarhije barijera egzistencijalni problemi;

- $\quad$ pretpostavlja se da neka socijalno-demografska obilježja determinišu barijere obrazovanja i indeks obrazovnog osujećenja odraslih.

Istraživački uzorak obuhvatio je 251 ispitanika sa teritorije opštine Nikšić. Za navedeni uzorak opredijelili smo se iz tog razloga što Nikšić smatramo tipičnom sredinom koja je karakteristična za veći dio Crne Gore 
(dakle namjerno smo izbjegli Podgoricu, koja predstavlja atipičan primjer i u velikoj mjeri se razlikuje od ostalih gradova u Crnoj Gori). Osim toga, za navedeni uzorak opredijelili smo se i zbog materijalno-tehničkih, prostornih i vremenskih ograničenja,jer smo na taj način olakšali organizaciju realizovanog istraživanja. Budući da su istraživanjem obuhvaćeni samo odrasli sa teritorije opštine Nikšić, realno je očekivati da bi rezultati bili objektivniji, potpuniji i pouzdaniji da smo istraživanjem obuhvatili i ostale regije Crne Gore (sjevernu, primorsku i još neke gradove centralne regije).

Instrument smo koncipirali na osnovu rezultata prethodnih istraživanja, čijom smo se analizom bavili. U prvom dijelu upitnika od ispitanika se tražilo da preciziraju neke opšte lične podatke (pol, godine starosti, nivo obrazovanja...). Zatim, u drugom dijelu instrumenta od ispitanika se tražilo da procijene vrijednost navedenih tvrdnji, koje su u vezi sa barijerama obrazovanja, ocjenom od 1 do $5, \mathrm{~s}$ tim što je ocjena 1 predstavljala najnižu, a ocjena 5 najvišu vrijednost.

\section{Interpretacija i diskusija dobijenih rezultata}

Najprije smo utvrdili hijerarhiju barijera obrazovanja odraslih, a zatim smo nastojali da utvrdimo da li postoji statistički značajna povezanost između seta socijalno-demografskih obilježja ispitanika i barijera obrazovanja odraslih. Na kraju, odlučili smo da izračunamo ukupni nivo obrazovnog osujećenja naših ispitanika i da ih svrstamo u tri kategorije: ispitanici koji imaju nizak, umjeren i visok nivo (indeks) obrazovnog osujećenja, a nakon toga da utvrdimo da li postoji statistički značajna korelacija između indeksa obrazovnog osujećenja i socijalno-demografskih obilježja ispitanika.

\section{Hijerarhija barijera obrazovanja odraslih}

Kako je i definisano ciljem istraživanja, najprije smo se bavili hijerarhijom barijera obrazovanja odraslih. Nadalje smo interesovanje usmjerili na hijerarhije barijera obrazovanja zaposlenih i nezaposlenih, kako bismo uočili moguće razlike i sličnosti i pristupili njihovoj analizi i diskusiji o njima.

Dobijeni podaci poduzetog istraživanja nam pokazuju da primarno mjesto u hijerarhiji barijera obrazovanja odraslih zauzima nedostatak novca. Zatim se nedostatak vremena, odnosno previše obaveza na poslu i u porodici vidi kao značajna barijera obrazovanja. Nakon toga se, po intenzitetu, izdvaja nedostatak interesantnih (praktičnih) programa kao faktor koji determiniše neparticipaciju odraslih u obrazovanju. Visok rang u hijerarhiji barijera obrazovanja odraslih 
(4. mjesto) zauzima nedostatak institucija koje nude programe obrazovanja namijenjene odraslima. Nadalje slijede barijere: zadovoljstvo postojećim znanjem, nemogućnost upotrebe stečenog znanja, neisplativost obrazovanja, nedostatak informacija o mogućnostima obrazovanja, godine starosti kao nepogodno vrijeme za učenje, nedostatak interesovanja, udaljenost institucije, nedovoljno praktična vrijednost obrazovanja, obrazovanje ne pričinjava zadovoljstvo, nedostatak samopouzdanja. $\mathrm{Na}$ dnu hijerarhije su barijere koje se tiču neujednačenosti grupe sa kojom pojedinac uči i nedostatak podrške od porodice.

Kako nam pokazuju prethodni podaci, na vrhu hijerarhije barijera su upravo određeni egzistencijalni problemi - primarno mjesto zauzimaju nedostatak novca i nedostatak vremena. I brojna druga empirijska istraživanja potvrđuju da su upravo ovo glavne barijere participacije odraslih u učenju i obrazovanju. Odrasli su najčešće prinuđeni da sami investiraju u obrazovanje, tj. najčešće su u situaciji da sami snose troškove obrazovnih aktivnosti, jer poslodavci i lokalne zajednice često nijesu spremni da ulažu sredstva (novac) u obrazovanje odraslih. Stoga je i opravdano da barijera nedostatak novca ima najviši rang u hijerarhiji barijera. Nedostatak vremena je druga najznačajnija barijera obrazovanja odraslih. Zapravo, previše obaveza na poslu, i briga o djeci su zaista česti razlozi neparticipacije, što potvrđuju rezultati brojnih empirijskih studija. Savremen način života odraslih donio je i izmijenjeno radno vrijeme, tako da pojedinci sve manje imaju slobodnog vremena koje bi mogli iskoristiti za različite obrazovne aktivnosti. Visoko mjesto (rang) u hijerarhiji barijera obrazovanja zauzimaju nedostatak interesantnih programa i nedostatak institucija koje nude obrazovne programe namijenjene odraslima. Institucionalne barijere su čest faktor osujećenja participacije odraslih u obrazovanju. U mnogim sredinama ne postoji dovoljan broj institucija, koje imaju savremene, kvalitetne obrazovne programe. Dakle, svaka društvena zajednica bi trebalo da razvije institucionalnu infrastrukturu obrazovanja odraslih, i da programi koje nude budu utemeljeni na potrebama privrede, ekonomije, tržišta rada $i$, svakako, pojedinca. Zadovoljstvo postojećim znanjem takođe ima visok rang u hijerarhiji barijera (5. pozicija). Nerijetko pojedinci smatraju da imaju dovoljno znanja koje im je potrebno za obavljanje određenih radnih zadataka. Međutim, ako se osvrnemo na promjene koje se intenzivno dešavaju u svim sferama života, i ako uzmemo u obzir činjenicu da upravo zbog tih promjena čovjekova znanja zastarijevaju, onda ne možemo opravdati stav da pojedinac može biti zadovoljan znanjem koje ima. Stoga smatramo da bi trebalo pronaći puteve i načine za podizanje svijesti svih ljudi 
u našem društvu o potrebi i neizbježnosti doživotnog učenja. Nemogućnost upotrebe stečenog znanja, kao barijera participacije, može se prevazići ukoliko organizatori obrazovanja odraslih prate promjene i programe prilagođavaju potrebama pojedinaca. Osim toga, neisplativost obrazovanja je takođe značajan faktor osujećenja participacije. Odrasli zapravo moraju provjeriti da li će vrijeme i novac koji ulože u neku obrazovnu aktivnost biti isplativi, odnosno da li će moći da nadoknade uloženo vrijeme i novac, uzimajući u obzir godine koje su im preostale za ostvarivanje radnog odnosa. Nedostatak informacija o mogućnostima obrazovanja zauzima središnje mjesto u hijerarhiji barijera obrazovanja odraslih. Često ljudima nijesu dostupne informacije o mogućnostima obrazovanja, o postojanju institucija za obrazovanje odraslih i programima koje nude. Upravo bi ovo moglo biti od značaja za organizatore obrazovanja odrsalih da na bolji način i putem medija promovišu svoje programe kako bi se broj participanata povećao. U hijerarhiji nadalje slijede barijere koje se tiču stavova i percepcije ispitanika o obrazovanju. $\mathrm{Na}$ dnu hijerarhije su, kako smo već istakli, neujednačenost obrazovnih grupa i nedostatak podrške porodice.

Kako smo već istakli, nadalje nas je u istraživanju zanimalo da li postoji razlika u rangiranju barijera obrazovanja kada ispitanike svrstamo u kategorije zaposlenih i nezaposlenih.

Analizirajući dobijene podatke, uočavamo da postoje izvjesne razlike u rangiranju barijera obrazovanja kada ispitanike svrstavamo u dvije kategorije - zaposleni i nezaposleni. Naime, zaposleni najviši rang dodjeljuju barijeri nedostatak vremena, dok je ona kod nezaposlenih na 7. poziciji (ispitanici su ponuđene barijere rangirali od 1. do 16. pozicije). Zapravo, zaposleni s obzirom na radne uloge i angažovanost i porodične obaveze imaju manje vremena za participiranje u obrazovanju u odnosu na nezaposlene, koji imaju više vremena samim tim što nijesu u radnom odnosu, te i ovu barijeru opravdano različito ranguju. Za obje kategorije ispitanika, nedostatak novca se ističe kao izrazito značajna barijera obrazovanja. Razumljivo je da nezaposleni - oni koji nemaju određene prihode, nedostatak novca procjenjuju kao ključni faktor osujećenja participacije u obrazovanju. Kako smo i ranije isticali, odrasli najčešće moraju sami da investiraju u obrazovanje, te je ovaj faktor zaista čest uzrok neparticipacije, što potvrđuju i rezultati prethodnih istraživanja. I zaposlenima je nedostatak novca jedna od ključnih barijera oni moraju da obezbjeđuju egzistenciju sebi i svojim članovima porodice, a imajući u vidu prosječan lični dohodak u našoj zemlji (prosječna neto zarada u ulu 2012. godine iznosila je 480 eura $)^{5}$, ne iznenađuje nas ovakvo rangiranje

5 www.monstat.org. Dostupno: [15. 6. 2012.]. 
barijere nedostatak novca, jer je vrlo teško izdvojiti određena sredstva za obrazovne aktivnosti. Sličnosti su u rangiranju institucionalnih barijera koje su u vezi sa nedostatkom institucija koje nude programe namijenjene odraslima i nedostatkom interesantnih i praktičnih programa. Upravo nam to ukazuje da na teritoriji opštine Nikšić, prema mišljenju naših ispitanika, ne postoji dovoljan broj institucija i različitih obrazovnih programa, što svakako zahtijeva posebnu i dublju objektivnu analizu. Nezaposleni visoko ranguju i barijeru nemogućnost upotrebe stečenog znanja. Upravo zbog nemanja posla, ovi ispitanici ne vide mogućnost upotrebe stečenog znanja. Sličnosti se ogledaju u rangiranju barijera koje se tiču nedostatka samopouzdanja, neujednačenosti obrazovne grupe i podrške porodice, koje se ujedno nalaze na dnu hijerarhije barijera i kod zaposlenih i nezaposlenih ispitanika.

Uzimajaću u obzir prvih pet barijera iz hijerarhije barijera nezaposlenih lica, a potpuno svjesni rizika pretjerane simplifikacije, mogli bismo kazati da profil potencijalnog participanta u obrzovanju odraslih u Nikšiću izgleda ovako: nema novca, nema programe, nema institucije, ne može da upotrijebi stečeno znanje i uglavnom je zadovoljan znanjem koje posjeduje.

\section{Povezanost socijalno-demografskih obilježja i barijera obrazovanja odraslih}

Tokom istraživanja nastojali smo da utvrdimo da li postoji povezanost između određenih socijalno-demografskih obilježja ispitanika i barijera obrazovanja odraslih. Upravo rezultati brojnih empirijskih studija pokazuju da su često barijere obrazovanja odraslih, kao i motivi, determinisani različitim karakteristikama ispitanika, odnosno polom, godinama starosti, nivoom obrazovanja i sl. Shodno tome, naša namjera je bila da utvrdimo povezanost ovih varijabli na uzorku koji smo odabrali.

\section{Godine starosti i barijere obrazovanja odraslih}

Rezultati do kojih smo došli tokom istraživanja pokazuju da postoji korelacija između godina starosti i barijere - smatram da moje godine nijesu pogodne za učenje. Zapravo, odgovori respondenata pokazuju da ispitanici koji su iznad 41 godine starosti navedenu barijeru vrednuju visokim ocjenama, dok ispitanici mlađih godina ovu barijeru ocjenjuju najnižim ocjenama. Dobijeni podaci ukazuju da je kod nas još uvijek dominantan kulturni obrazac da je učenje namijenjeno mladima, tj. da odrasli ljudi nemaju sposobnosti i mogućnosti za učenje. Ovakav stav, kako je poznato, zastupale su pristalice tzv. 
teorije plastičnosti. Međutim, Torndajk, američki psiholog, eksperimentalnim putem je dokazao da odrasli ljudi sa godinama starosti ne gube sposobnosti za učenje, i time opovrgao prethodno pomenute tvrdnje . Ali, rezultati do kojih smo došli pokazuju da dosta velik broj ispitanika, koji pripadaju grupi starijih odraslih, smatra da su godine starosti velika barijera, odnosno faktor osujećenja i ometanja njihove participacije u obrazovnim aktivnostima.

Dalje, rezultati istraživanja pokazuju da postoji povezanost između godina satrosti i barijere - obrazovanje mi ne pričinjava zadovoljstvo. Dobijeni podaci upućuju na opšti zaključak da sa porastom godina starosti obrazovanje postaje aktivnost koja je sve manje povezana sa zadovoljstvom. Zapravo rezultati istraživanja pokazuju da mlađi odrasli u veoma velikom procentu navedenu barijeru vrednuju najnižim ocjenama, za razliku od starijih odraslih. Mišljenja smo da stariji odrasli smatraju da njihove godine nijesu pogodne za učenje i obrazovanje, te samim tim obrazovanje im nerijetko i ne pričinjava zadovoljstvo. Za razliku od njih, mlađi odrasli obrazovanje doživljavaju kao aktivnost od koje imaju brojne koristi, te samim tim i svjesni su svih promjena koje se dešavaju u okruženju i koliko im učenje i obrazovanje pomaže u adaptaciji i praćenju tih promjena.

Nadalje, rezultati istraživanja pokazuju da postoji povezanost između godina starosti i barijere obrazovanja - nemam interesovanje za dalje učenje (nedostatak energije), u smislu da stariji odrasli pokazuju manji interes za učenje. Dakle, kod starijih odraslih ispitanika navedena barijera je zastupljenija kao faktor ometanja participacije u obrazovanju u odnosu na mlađe odrasle. Smatramo da mlađi odrasli imaju više interesovanja za obrazovne aktivnosti jer su na početku karijere, ili pak, ako su nezaposleni, dalje obrazovanje im može pomoći u dobijanju posla. Za razliku od njih, stariji odrasli nerijetko pokazuju nedovoljno interesovanja za participaciju u obrazovanju, a razlozi za to su brojni, jer je participacija u obrazovanju uslovljena životnom situacijom ispitanika i mogućnostima okruženja. Osim toga, stariji odrasli smatraju da učenje nije pogodna aktivnost u njihovim godinama i da je ono isključivo namijenjeno mlađima, te i ovo može biti jedan od razloga nedostatka interesovanja za participaciju u učenju i obrazovanju.

Dalje, odgovori respondenata pokazuju da postoji korelacija između godina starosti i barijere obrazovanja - neujednačenost grupe sa kojom učim (imamo različite sposobnosti i teško mi je da se uklopim). Dobijeni rezultati pokazuju da je neujednačenost obrazovne grupe značajnija barijera obrazovanja za starije odrasle, u odnosu na mlađe odrasle ispitanike. U praksi je obrazovne grupe odraslih zaista teško ujednačiti i postići homogenost grupe kao što je to 
slučaj sa djecom i mladima. Prije svega, odrasli ljudi koji participiraju u nekoj obrazovnoj aktivnosti su različitih godina starosti, pola, nivoa obrazovanja, profesije, socijalnog statusa i sl. te je samim tim i jasno zašto je teško sasvim ujednačiti obrazovne grupe. No, organizatori obrazovnih programa bi trebalo da nastoje da postignu homogenost u što većoj mjeri. Kako nam rezultati istraživanja pokazuju, stariji odrasli neujednačenost grupe sa kojom uče ocjenjuju kao veoma značajan faktor osujećenja participacije u odnosu na mlađe odrasle. Zapravo, poznate su fiziološke promjene koje se dešavaju u odrasloj dobi, te samim tim stariji ljudi opažaju, misle i reaguju mnogo sporije u odnosu na mlađe. Stoga i u konkretnoj obrazovnoj aktivnosti za učenje, obavljanje određenih zadataka, potrebno im je više vremena i objašnjenja u odnosu na mlađe, što je svakako barijera prilikom učenja u grupi, pogotovo u heterogenoj, s obzirom na godine starosti.

Nadalje, rezultati istraživanja pokazuju da postoji statistički značajna povezanost između godina starosti i barijere - ne vidim svrhu i praktičnu vrijednost obrazovanja. Rezultati do kojih smo došli ukazuju da stariji odrasli nemogućnost upotrebe stečenog znanja ocjenjuju kao značajnu barijeru participacije u odnosu na mlađe odrasle. Mišljenja smo da stariji odrasli, s obzirom na godine starosti, smatraju da znanje koje bi dobili uključivanjem u neku obrazovnu aktivnost ne mogu sasvim iskoristiti. Šta to zapravo znači? Stariji odrasli su pri kraju radnog vijeka, te samim tim pitaju se kakva je svrha njihovog obrazovanja i da li će uloženo vrijeme, novac, energija biti isplativi, odnosno da li će im obrazovanje donijeti toliko koristi kako bi mogli nadoknaditi troškove uložene u obrazovanje. Osim toga, postoji mogućnost da obrazovni programi nijesu dovoljno praktični, da ih ne mogu upotrijebiti u određenoj radnoj situaciji. Za razliku od njih, mlađi odrasli, kako smo više puta isticali, s obzirom da su na početku karijere imaju mnogo više vremena da stečeno znanje iskoriste, primijene, te da im bude isplativo ulaganje $u$ obrazovanje. Stoga je sasvim prirodna razlika koja postoji u odgovorima između starijih i mlađih odraslih.

\section{Povezanost nivoa obrazovanja i barijera obrazovanja odraslih}

Rezultati istraživanja pokazuju da nivo obrazovanja determiniše određene barijere obrazovanja odraslih. Prilikom analize i inetrpretacije dobijenih rezultata nijesmo uzimali u obzir odgovore ispitanika koji imaju nepotpunu ili završenu osnovnu školu, jer je njihov broj, koji je uzorkom obuhvaćen, u velikoj mjeri manji od broja ispitanika sa završenom srednjom ili visokom školom. 
Dobijeni podaci ukazuju da postoji povezanost između nivoa obrazovanja i barijere - nedostatak podrške porodice u smislu da ispitanici sa višim nivoom obrazovanja u najvećoj mjeri porodicu ne doživljavaju kao faktor ometanja participacije u učenju i obrazovanju. Dakle, ispitanici koji imaju završen zanat ili srednju školu, barijeru - nedostatak podrške porodice, ocjenjuju kao značajan faktor osujećenja njihove participacije u obrazovnim aktivnostima. Za razliku od njih, za ispitanike sa završenom višom ili visokom školom ova barijera nije toliko značajna ili pak u mnogo nižem procentu u odnosu na prethodnu grupu ispitanika. Mišljenja smo da pojedinci sa završenom visokom školom žive u porodicama koje razumiju njihove uloge na poslu i odgovornosti, te samim tim pružaju im podršku za kontinuirano obrazovanje, usavršavanje, cjelokupno za participaciju u učenju i obrazovanju. Na drugoj strani, pitamo se zašto ispitanicima sa završenom srednjom školom ili zanatom nedostaje podrška porodice? Ili pak zašto nedostaje u većoj mjeri u odnosu na ispitanike sa visokim nivoom obrazovanja? Moguće je da se porodice ispitanika sa nižim nivoom obrazovanja nalaze u nepovoljnijoj socijalno-ekonomskoj situaciji, te samim tim izostaje podrška za uključivanje u obrazovanje, prije svega zbog brojnih problema, kako finansijskih tako i socijalnih. Ove porodice prije očekuju angažman od svojih članova u nekim profesionalno-radnim aktivnostima, radi sticanja dodatne zarade nego $u$ aktivnostima obrazovanja.

Nadalje, rezultati istraživanja pokazuju da postoji statistički značajna korelacija kada je u pitanju nivo obrazovanja i barijera - smatram da moje godine nijesu pogodne za učenje. Ukoliko uporedimo rezultate navedenih grupa, uočavamo da ispitanici sa nižim nivoom obrazovanja u mnogo većem procentu navedenu barijeru vrednuju visokim ocjenama (4 i 5) u odnosu na ispitanike sa višim nivoom obrazovanja. Dok se za ocjenu 1 u mnogo većem procentu izjašnjavaju ispitanici sa visokim nivoom obrazovanja.

Dalje, odgovori ispitanika pokazuju da postoji povezanost između nivoa obrazovanja i barijere - obrazovanje mi ne pričinjava zadovoljstvo. Naime rezultati poduzetog istraživanja pokazuju da je i ova barijera značajnija za ispitanike sa nižim nivoom obrazovanja, u odnosu na ispitanike koji imaju završenu višu ili visoku školu.

Dakle, ispitanici sa nižim nivoom obrazovanja barijere - smatram da moje godine nijesu pogodne za učenje i obrazovanje mi ne pričinjava zadovoljstvo, ocjenjuju kao jake faktore osujećenja participacije u obrazovanim aktivnostima $u$ odnosu na ispitanike sa višim nivoom obrazovanja, tj. rezultati istraživanja pokazuju da postoji značajna razlika u odgovorima 
između navedenih grupa ispitanika. Smatramo da su ispitanici sa nižim nivoom obrazovanja skloniji da prihvataju predrasude koje postoje u nekom društvu, pa je i jedna od njih ta da je obrazovanje namijenjeno djeci i mladima i da odrasli nemaju sposobnosti i mogućnosti za učenje. Osim toga, kao što je ranije naglašeno ispitanici sa višim nivoom obrazovanja, nerijetko zbog poslova koje obavljaju su ,prinuđeni,, da se profesionalno usavršavaju i uključuju u različite obrazovne aktivnosti, dok ispitanici sa nižim nivoom obrazovanja obavljaju poslove nižeg socijalnog statusa, te samim tim imaju i mnogo manje mogućnosti da se stručno usavršavaju i uključuju u učenje i obrazovanje iz raznovrsnih potreba koje zahtijeva radno mjesto. Mišljenja smo da su ispitanici sa visokim nivoom obrazovanja svjesniji neophodnosti učenja u svim periodima života, kako bi se mogli prilagoditi promjenama koje se dešavaju u svijetu, te i njihovom poslovnom i porodičnom okruženju. Dok ispitanici sa nižim nivoom obrazovanja vjerovatno prihvataju stav da se sa završetkom formalnog školovanja završava i njihovo učenje. Osim toga, dobijeni rezultati pokazuju da postoji razlika u odgovorima ispitanika kada je u pitanju barijera - obrazovanje mi ne pričinjava zadovoljstvo. Uočavamo da ispitanici sa nižim nivoom obrazovanja učenje i obrazovne aktivnosti u manjoj mjeri doživljavaju kao zadovoljstvo u odnosu na ispitanike sa višim nivoom obrazovanja. Smatramo da ispitanici sa nižim obrazovnim nivoom imaju više finansijskih, i svih drugih problema u odnosu na ispitanike sa visokim nivoom obrazovanja. Shodno tome, obrazovanje posmatraju kao sredstvo koje im može pomoći da poboljšaju vlastiti socijalno-ekonomski položaj i zbog zaokupljenosti egzistencijalnim problemima nijesu u mogućnosti da spoznaju sve ostale vrijednosti obrazovnih aktivnosti. Sa druge strane, ispitanici sa visokim nivoom obrazovanja, svjesni svih koristi koje donose učenje i obrazovanje, a u skladu sa nivoom obrazovanja obavljaju poslove koji imaju visok socijalni status i društveni ugled, imaju mnogo manje egzistencijalnih problema, te samim tim u obrazovanju otkrivaju druge vrijednosti, žele da dostignu samoaktualizaciju, da maksimalno razviju svoje potencijale i ličnost u cjelini. Upravo zbog navedenih razloga obrazovanje doživljavaju kao aktivnost koja im donosi mnogo duhovnog bogatstva, osim neposrednih koristi. Za razliku od njih, smatramo da su ispitanici sa nižim nivoom obrazovanja najčešće primorani da participiraju u obrazovanju zbog nekih egzistencijalnih problema, pa usljed takve situacije i ne mogu da spoznaju ostale dobrobiti samog procesa učenja.

Nadalje, rezultati istarživanja pokazuju da postoji korelacija kada su u pitanju nivo obrazovanja i barijera - nedostatak samopouzdanja i nepovjerenje 
$u$ vlastite sposobnosti. Dakle, uočljivo je da za ispitanike sa visokim nivoom obrazovanja nedostatak samopouzdanja, odnosno nepovjerenje u vlastite sposobnosti, ne predstavlja značajnu barijeru obrazovanja, dok je za ispitanike sa završenim zanatom ili srednjom školom ipak u većoj mjeri ocijenjena kao faktor ometanja participacije u programima obrazovanja.

Rezultati istraživanja pokazuju da postoji povezanost kada je u pitanju nivo obrazovanja i barijera - neujednačenost grupe sa kojom učim. Podaci do kojih smo došli pokazuju da ispitanici sa nižim nivoom obrazovanja daju ocjene 2, 3, 4 i 5 u mnogo većem procentu u odnosu na ispitanike sa višim nivoom obrazovanja, koji imaju veći procenat za ocjenu 1, kao najnižu vrijednost.

Dobijeni rezultati potvrđuju da nivo obrazovanja determiniše brojne barijere obrazovanja odraslih. Rezultati poduzetog istraživanja pokazuju nam da postoji značajna razlika u odgovorima između ispitanika sa završenom srednjom školom i ispitanika sa završenom višom ili visokom školom. Zapravo, za ispitanike sa nižim nivoom obrazovanja nedostatak samopouzdanja, kao i neujednačenost grupe sa kojom uče su značajnije barijere u odnosu na ispitanike sa završenom višom ili visokom školom. Dakle, ispitanici sa nižim nivoom obrazovanja imaju manje povjerenja $\mathrm{u}$ vlastite sposobnosti, što je uglavnom uslovljeno nivoom obrazovanja. Upravo zbog različitih sposobnosti participanata, obrazovna grupa može biti značajna barijera obrazovanja odraslih. Mišljenja smo da se ispitanici sa nižim nivoom obrazovanja, upravo zbog svog inicijalnog obrazovanja, (ne) uspjeha tokom školovanja, teže prilagođavaju u različitim situacijama koje su u vezi sa obrazovanjem, te samim tim nerijetko izostaje i samopouzdanje koje je potrebno za uspješan proces učenja. Prirodno je da pojedinci sa visokim nivoom obrazovanja imaju dovoljno samopouzdanja i povjerenja u vlastite sposobnosti, i da se lakše prilagođavaju različitim obrazovnim grupama.

\section{Bračni, porodični i radni staus i barijere obrazovanja odraslih}

Odgovori respondenata pokazuju da bračni status determiniše neke barijere obrazovanja odraslih. Naime, rezultati istraživanja ukazuju da postoji korelacija između bračnog statusa i nedostatka vremena kao barijere obrazovanja. Rezultati pokazuju da je nedostatak vremena značajnija barijera za ispitanike koji su u braku, u odnosu na one koji nijesu. Dakle, nedostatak vremena, kao barijera obrazovanja, više je izražena kod ispitanika koji su braku. Zapravo, previše obaveza na poslu i u porodici su svakako jak faktor osujećenja participacije u obrazovnim aktivnostima. Prirodno je 
da ispitanici koji su u braku, prije svega zbog obaveza u porodici (osim onih na poslu), imaju zaista manje slobodnog vremena koje bi mogli koristiti za zadovoljavanje obrazovnih potreba, tj. participaciju u učenju i obrazovanju. Stoga bi organizatori obrazovnih programa trebalo da imaju u vidu obaveze potencijalnih participanata i obrazovne programe prilagode njihovim obavezama, a ukoliko je moguće u sklopu centara za obrazovanje odraslih i za vrijeme časova organizuju neke aktivnosti za djecu čiji su roditelji uključeni u konkretnu obrazovnu aktivnost.

Nadalje, rezultati istraživanja pokazuju da postoji povezanost između porodičnog statusa, roditeljstva (podatak da li imaju djecu ili ne) i barijere obrazovanja - nedostatak vremena (previše obaveza na poslu i u porodici). Naime, za ispitanike koji imaju djecu, barijera - nedostatak vremena, odnosno previše obaveza na poslu i u porodici značajnija je u odnosu na ispitanike koji nemaju djecu. Dakle, uočljivo je da postoji značajna razlika u ocjenjivanju barijere - nedostatak vremena između ispitanika koji imaju i onih koji nemaju djecu. Prirodno je da ispitanici koji imaju djecu u mnogo većem procentu daju ocjenu $5 \mathrm{u}$ odnosu na ispitanike koji nemaju djecu, jer zaista imaju više obaveza u porodici, što uzrokuje sve manje slobodnog vremena koje bi mogli koristiti u obrazovne svrhe.

Dalje, rezultati istraživanja pokazuju da postoji korelacija kada je u pitanju roditeljstvo i barijera - smatram da moje godine nijesu pogodne za učenje. Dobijeni podaci ukazuju da postoji značajna razlika u ocjenjivanju barijere - smatram da moje godine nijesu pogodne za učenje, između ispitanika koji imaju i onih koji nemaju djecu. Mišljenja smo da ispitanici koji imaju djecu, upravo zbog obaveza i odgovornosti koje imaju u porodici i na poslu, navedenu barijeru doživljavaju kao značajan faktor osujećenja participacije u obrazovnim aktivnostima. Stav da je obrazovanje namijenjeno djeci i mladima, a ne i odraslima, vjerovatno je dodatno potkrijepljen činjenicom da imaju djecu koja se školuju, te nije ,prirodno,, da se roditelji i djeca istovremeno obrazuju. Za razliku od njih, ispitanici koji nemaju djecu, u dosta manjoj mjeri navedenu barijeru ocjenjuju kao faktor ometanja participacije u učenju i obrazovanju.

Nadalje, rezultati istraživanja pokazuju da postoji povezanost između radnog statusa (zaposlenost/nezaposlenost) i barijere nedostatak vremena, odnosno previše obaveza na poslu i u porodici. Zapravo, dobijeni rezultati pokazuju da ispitanici koji su zaposleni u mnogo većoj mjeri nedostatak vremena ocjenjuju kao važnu barijeru obrazovanja u odnosu na ispitanike koji su nezaposleni. Prirodno je i očekivano da ispitanici koji su zaposleni, 
nedostatak vremena ocijene kao značajnu barijeru participacije u obrazovanju, u odnosu na nezaposlene. Zaposlenje i druge obaveze umanjuju slobodno vrijeme koje bi pojedinci mogli da investiraju u obrazovne aktivnosti. Na drugoj strani, nezaposleni imaju mnogo više slobodnog vremena koje bi upravo mogli racionalno da koriste time što će se uključiti u neku obrazovnu aktivnost, a koja im može biti od koristi u traženju ili pak dobijanju posla. Smatramo da ova barijera sve više dolazi do izražaja u savremenom društvu, gdje se broj radnih sati povećava do te mjere da čovjek sve manje ima vremena koje bi provodio sa porodicom - koliko onda ostaje slobodnog vremena koje bi se moglo iskoristiti za obrazovanje i učenje?

\section{Profesionalna pripadnost i barijere obrazovanja odraslih}

Rezultati poduzetog istraživanja pokazuju da profesija determiniše neke barijere obrazovanja odraslih. Naime, odgovori ispitanika ukazuju da postoji korelacija između profesionalne pripadnosti i barijere obrazovanja - porodica to ne želi (nedostatak podrške). Dakle, odgovori respondenata pokazuju da je barijera - nedostatak podrške porodice za participaciju u obrazovnim aktivnostima značajnija za profesiju radnika, u odnosu na stručnjake, inženjere ili prosvjetne radnike. Smatramo da se profesija i navedena barijera mogu povezati sa nivoom obrazovanja. Zapravo, porodice stručnjaka, inženjera, prosvjetnih radnika su naviknute na činjenicu da se njihovi članovi moraju kontinuirano obrazovati kako bi mogli da napreduju i sačuvaju ugled i status koji imaju u određenoj profesiji. Dok na drugoj strani, porodice radnika ili administrativnog osoblja, pretpostavljamo, imaju lošiju socijalno-ekonomsku poziciju, te samim tim mnogo manje interesovanja za obrazovanje svojih članova. Prethodno smo isticali da određene profesije zahtijevaju permanentno profesionalno usavršavanje i praćenje promjena $u$ struci. Shodno tome, sa sigurnošću tvrdimo, da će porodice pojedincima koji su ,prinuđeni,, na kontinuirano stručno usavršavanje, radi napredovanja u profesiji, dobijanja boljeg radnog mjesta, ili zadržavanja pozicije koju imaju, pružiti podršku za participaciju u učenju i obrazovanju, jer je to neophodno za egzistenciju njihovih članova.

Nadalje, rezultati istraživanja pokazuju da postoji povezanost kada je u pitanju profesija i barijera obrazovanja - smatram da moje godine nijesu pogodne za učenje. Naime, dobijeni podaci ukazuju da je barijera - smatram da moje godine nijesu pogodne za učenje, značajniji faktor osujećenja participacije za radnike, a nakon njih i administrativno osoblje u odnosu na inženjere, prosvjetne radnike i stručnjake. Budući da profesiju možemo 
povezati sa nivoom obrazovanja, uočavamo da je radnici u neposrednoj proizvodnji i administrativno osoblje (ispitanici sa nižim nivoom obrazovanja) u mnogo većem procentu vrednuju ocjenom 5 , u odnosu na ispitanike sa visokim nivoom obrazovanja, $\mathrm{tj}$. inženjere, prosvjetne radnike i stručnjake. Svakako se ovo može povezati i sa poslovima koje obavljaju, u smislu da su ispitanici iz profesija koje zahtijevaju visok nivo obrazovanja često i prinuđeni da participiraju u obrazovnim aktivnostima upravo zbog profesije i posla koji obavljaju, te samim tim godine starosti ne mogu doživljavati kao važnu barijeru obrazovanja. Na drugoj strani, radnici i administrativno osoblje (ispitanici sa nižim nivoom obrazovanja), imaju manje mogućnosti da napreduju u profesiji, poslovi koje obavljaju su najčešće manje zahtjevni i ne iziskuju kontinuirano učenje, te stav da odraslo doba nije pogodno za učenje lako prihvataju.

Dalje, rezultati istraživanja pokazuju da postoji povezanost između profesije i barijere obrazovanja - neujednačenost grupe sa kojom učim. $\mathrm{Na}$ osnovu dobijenih podataka uočavamo da je neujednačenost grupe, kao barijera obrazovanja, značajnija za radnike i administrativno osoblje u odnosu na inženjere, prosvjetne radnike i stručnjake. Mišljenja smo da je povezanost neujednačenosti obrazovne grupe i profesije jednaka korelaciji nivoa obrazovanja i neujednačenosti obrazovne grupe. Zapravo, ispitanici sa nižim inicijalnim nivoom obrazovanja (radnici i administrativno osoblje) teže se prilagođavaju različitim obrazovnim grupama u odnosu na ispitanike s visokim nivoom obrazovanja.

Tokom obrade podataka odlučili smo da nezavisnu varijablu - profesonalna pripadanost, operacionalizujemo na dva indikatora: radnici i stručnjaci. Dakle, u kategoriju radnika svrstali smo radnike u neposrednoj proizvodnji, administrativno osoblje i ostale, a u kategoriju stručnjaka: inženjerskotehničke kadrove, prosvjetne radnike i stručnjake (pravnike i ekonomiste). Imali smo namjeru da utvrdimo da li postoji korelacija između profesije, kada je operacionalizovana na dva indikatora, i barijera obrazovanja odraslih.

Rezultati istraživanja pokazuju da postoji korelacija između profesije i barijere - obrazovanje mi ne pričinjava zadovoljstvo. Dakle, dobijeni podaci ukazuju da je za radnike navedena barijera značajan faktor osujećenja participcije u učenju i obrazovanju, u odnosu na stručnjake.

Nadalje, rezultati istraživanja pokazuju da postoji korelacija kada je u pitanju profesija i barijera obrazovanja-nemam interesovanje za dalje učenje. Odgovori respondenata nam pokazuju da je barijera obrazovanja odraslih nemam interesovanje za dalje učenje, važan faktor ometanja participacije 
u obrazovnim aktivnostima za kategoriju radnika u odnosu na kategoriju stručnjaka.

Prethodno navedeni podaci pokazuju da ispitanici koji su u grupi radnika barijere - obrazovanje mi ne pričinjava zadovoljstvo i nemam interesovanje za dalje učenje, izdvajaju kao značajnije faktore osujećenja participacije u obrazovanju, za razliku od ispitanika koji pripadaju kategoriji stručnjaka. Mišljenja smo da navedene barijere determiniše nivo obrazovanja koji se odražava kroz profesiju. Jer, radnici (ispitanici sa nižim nivoom obrazovanja) pokazuju da nemaju dovoljno interesovanja za dalje učenje i istovremeno obrazovanje im ne pričinjava zadovoljstvo. Zapravo, njihove profesije (poslovi koje obavljaju) ne omogućavaju im dalje napredovanje, i poboljšanje socijalnog statusa, te samim tim nijesu ni zainteresovani za dalje učenje $i$ obrazovanje. Budući da su radnici u mnogo težoj socijalno-ekonomskoj poziciji u odnosu na stručnjake, trebalo bi poboljšati njihovo inicijalno obrazovanje i na taj način otvoriti mogućnost za napredovanje u profesiji, odnosno dobijanje boljeg radnog mjesta. Stručnjaci, tj. ispitanici sa visokim nivoom obrazovanja, prirodno je da pokazuju interesovanje za dalje učenje, i obrazovanje doživljavaju kao aktivnost koja im pričinjava zadovoljstvo. Oni su nerijetko „,prinuđeni,, da se kontinuirano usavršavaju zbog posla koji obavljaju. Međutim, smatramo da navedene barijere u najvećoj mjeri determiniše nivo obrazovanja, jer kako raste nivo obrazovanja tako rastu i obrazovni zahtjevi i potrebe. Shodno tome, i očekivana je razlika u odgovorima između navedenih kategorija ispitanika, tj. radnika i stručnjaka.

Dalje, rezultati poduzetog istraživanja pokazuju da postoji povezanost kada je u pitanju profesija i nedostatak samopouzdanja, kao barijera obrazovanja odraslih. Upravo podaci do kojih smo došli pokazuju da je za radnike nedostatak samopouzdanja, odnosno nepovjerenje u valstite sposobnosti, značajnija barijera obrazovanja u odnosu na stručnjake. Smatramo da stručnjaci zbog profesije i poslova koje obavljaju imaju jasniju sliku o vlastitim sposobnostima te samim tim i dovoljno samopouzdanja koje je potrebno da se uključe u neku obrazovnu aktivnost i da očekivane ishode učenja savladaju uspješno. Kako nam potvrđuju prethodno navedeni i prikazani rezultati poduzetog istraživanja, profesija u velikoj mjeri determiniše određene barijere obrazovanja odraslih. Postoje veoma velike razlike u ocjenjivanju barijera između različitih profesija i trebalo bi daljim istraživanjima tražiti i otkrivati uzroke koji dovode do toga. 


\section{Povezanost socijalno-demografskih obilježja i indeksa obrazovnog osujećenja}

Tokom istraživanja nastojali smo da saznamo koliki je ukupni indeks obrazovnog osujećenja ispitanika koji su obuhvaćeni uzorkom. Zapravo, sve ispitanike smo podijelili u tri kategorije: ispitanici koji imaju nizak, umjeren i visok nivo obrazovnog osujećenja. Nakon toga smo ispitali da li postoji značajna povezanost između određenih socijalno-demografskih obilježja i indeksa osujećenja ispitanika.

Dobijeni podaci pokazuju da je najviše ispitanika koji imaju umjeren nivo osujećenja, tj. njih 50.2\%, zatim $36.7 \%$ ispitanika koji imaju nizak nivo osujećenja i 13\% ispitanika koji imaju visok nivo osujećenja.

Dakle, polovina ispitanika koji su obuhvaćeni uzorkom imaju umjeren nivo osujećenja. Smatramo da 13\% ispitanika koji se izjašnjavaju da imaju visok nivo osujećenja nije zanemarljiv procenat. Poduzetim istraživanjem nastojali smo da utvrdimo hijerarhiju barijera obrazovanja odraslih kako bismo saznali koje su to ključne, najznačajnije barijere obrazovanja naših ispitanika. Rezultati do kojih smo došli mogu poslužiti u otklanjanju tih barijera kako bi se broj ispitanika koji imaju visok nivo osujećenja smanjio. Mišljenja smo da bi u nekim budućim istraživanjima pažnju trebalo usmjeriti na ispitanike koji imaju visok nivo osujećenja i kroz razgovor (intervju) otkriti koji su to njihovi glavni faktori osujećenja participacije u obrazovnim aktivnostima, kako bi nakon toga pojedinci, organizacije u kojima rade i zajednica u cjelini sistematski radili na otklanjanju barijera.

Kako smo već istakli, nakon dobijene strukture indeksa obrazovnog osujećenja nastojali smo da utvrdimo da li postoji povezanost sa nekim od socijalno-demografskih obilježja. Rezultati do kojih smo došli ukazuju da postoji korelacija kada su u pitanju indeks obrazovnog osujećenja i godine starosti.

Prethodno smo nezavisnu varijablu - godine starosti operacionalizovali na dva indikatora: ispitanici koji imaju od 20 do 40 godina i ispitanici koji su iznad 41 godine starosti. Analizirajući dobijene podatke uviđamo da mlađi odrasli u najvećem procentu imaju nizak, a stariji odrasli umjeren nivo obrazovnog osujećenja. Posebno se izdvaja razlika u procentima kada je $u$ pitanju visok i nizak nivo osujećenja. Naime, kod ispitanika iznad 41 godine starosti mnogo je veći procenat za visok nivo, a kod ispitanika od 20 do 40 godina starosti za nizak nivo osujećenja. Dakle, stariji odrasli cjelokupno imaju više barijera participacije u obrazovnim aktivnostima u odnosu na mlađe odrasle. Prije svega, stariji odrasli imaju mnogo manje vremena da 
sredstva i energiju koju su investirali u neku obrazovnu aktivnost „naplate,, tj. da im to obrazovanje bude isplativo. Osim toga, stariji odrasli se nerijetko i teže prilagođavaju u obrazovnoj grupi. Ukoliko već duže vrijeme nijesu bili uključeni u neku obrazovnu aktivnost, postoji strah od neuspjeha, nedovoljno povjerenja u sposobnosti i nedovoljno samopouzdanja. Sve ovo su barijere koje utiču na to da stariji odrasli imaju viši nivo osujećenja u odnosu na mlađe odrasle. Svakako, navedene rezultate ne treba generalizovati, mada brojne empirijske studije upravo navode razlike između mlađih i starijih odraslih i njihovu povezanost sa barijerama, a istovremeno i sa motivima obrazovanja.

Nadalje, rezultati istraživanja pokazuju da postoji povezanost između nivoa obrazovanja i indeksa obrazovnog osujećenja ispitanika. Prethodno smo nezavisnu varijablu - nivo obrazovanja - operacionalizovali na dva indikatora: osnovna škola/zanat/ srednja škola i viša/visoka škola. Dobijeni podaci ukazuju da ispitanici sa nižim nivoom obrazovanja u najvećem procentu imaju umjeren nivo osujećenja, a ispitanici sa visokim nivoom obrazovanja nizak nivo osujećenja. Dakle, podaci pokazuju da ispitanici sa nižim nivoom obrazovanja imaju mnogo više osujećenja, odnosno faktora koji ometaju participaciju u obrazovanju. Smatramo da je to prije svega zbog lošije socijalno-ekonomske pozicije koju imaju ovi pojedinci u odnosu na one koji su visokog nivoa obrazovanja. Osim toga, u skladu sa nivoom obrazovanja, obavljaju poslove koji su slabije plaćeni, imaju mnogo više različitih egzistencijalnih problema, te samim tim i zaista više barijera obrazovanja. Pored barijera koje su povezane sa egzistencijalnim problemima, nizak nivo obrazovanja determiniše i različite dispozicione barijere. Na primjer, rezultati poduzetog istraživanja pokazuju da ispitanici sa nižim nivoom obrazovanja kao veoma značajnu ocjenjuju barijeru nedostatak samopouzdanja, što svakako može biti povezano sa njihovim prethodnim iskustvom, obrazovnim postignućem, nivoom aspiracije i sl. Očigledno je da ispitanici sa nižim nivoom obrazovanja imaju više faktora koji ometaju njihovu participaciju u obrazovnim aktivnostima. Ovo saznanje može biti korisno za organizatore obrazovanja i za one koji su zaduženi za obrazovnu politiku odraslih kako bi mogli osmisliti startegiju za moguće i sistematsko prevazilaženje barijera obrazovanja kod ovog dijela populacije.

Dalje, odgovori ispitanika pokazuju da postoji korelacija kada je u pitanju roditeljstvo (podatak da li imaju djecu) i indeks obrazovnog osujećenja. Dakle, odgovori respondenata pokazuju da oni koji imaju djecu u mnogo većem procentu imaju visok nivo osujećenja u odnosu na ispitanike koji nemaju djecu. Postoji velika razlika u odgovorima kada je u pitanju nizak 
nivo osujećenja, koji je dominantniji kod pojedinaca koji nemaju djecu. Očekivano je da ispitanici koji imaju djecu istovremeno imaju i više barijera obrazovanja. Mišljenja smo da su neke barijere kao što su nedostatak vremena ili nedostatak novca primarne kod ispitanika koji imaju djecu. Respondenti koji imaju djecu, imaju i manje slobodnog vremena koje bi koristili za obrazovne aktivnosti. Pored toga, briga o djeci iziskuje i velika novčana sredstva, što opet utiče na nedostatak novca za investiranje u obrazovanje. Kako nam potvrđuju prethodni podaci, ispitanici koji imaju djecu, u najvećem procentu imaju umjeren nivo osujećenja, dok oni koji nemaju djecu imaju nizak nivo osujećenja.

Nadalje, rezultati istraživanja pokazuju da postoji korelacija između profesijei indeksa obrazovnog osujećenja. Nezavisnu varijablu-profesionalna pripadnost operacionalizovali smo na dva indikatora: radnici (radnici u neposrednoj proizvodnji, administrativno osoblje i ostali) i stručnjaci (inženjersko-tehnički kadrovi, prosvjetni radnici i stručnjaci). Rezultati istraživanja ukazuju da kod radnika dominira umjeren, dok kod stručnjaka nizak nivo obrazovnog osujećenja. Razlika u odgovorima ispitanika posebno je vidljiva kada je u pitanju visok i nizak nivo osujećenja. Dobijeni podaci potvrđuju da radnici imaju više faktora koji ometaju participaciju u obrazovnim aktivnostima u odnosu na stručnjake. Zapravo, profesija je povezana prije svega sa nivoom obrazovanja. Stoga stručnjaci obavljaju poslove koji su bolje plaćeni, te samim tim imaju manje egzistencijalnih problema u odnosu na radnike. Pored toga, stručnjaci imaju više realnih mogućnosti da napreduju u profesiji, da se stručno usavršavaju i da nakon zadovoljenja potreba nižeg reda ostvare i one više, kao što je samoaktualizacija. Imajući u vidu profesiju, i nivo obrazovanja, radnici imaju zaista više faktora koji ometaju njihovu participaciju u obrazovanju. Mišljenja smo da bi trebalo razviti mehanizme za otklanjanje barijera kod posebnih socijalnih kategorija, kao što su radnici.

\section{Zaključna razmatranja}

Rezultati poduzetog istraživanja pokazuju da najviši rang u hijerarhiji barijera ispitanici dodjeljuju nedostatku novca i nedostatku vremena. Dakle, riječ je o suštinskim problemima koji se odnose na čovjekovu egzistenciju. Uzimajući $\mathrm{u}$ obzir rezultate srodnih prethodnih istraživanja, u našem istraživanju pošli smo od pretpostavke da se na vrhu hijerarhije barijera obrazovanja nalaze egzistencijalni problemi, što potvrđuju i rezultati do kojih smo došli, te je samim tim naša polazna hipoteza vjerovatna.

Nadalje, rezultati do kojih smo došli pokazuju da godine starosti, nivo 
obrazovanja, profesija, bračni, porodični i radni status detreminišu brojne barijere obrazovanja odraslih. Pored toga, podaci do kojih smo došli pokazuju da najviše ispitanika ima umjeren nivo obrazovnog osujećenja. Međutim, $13 \%$ od ukupnog broja ispitanika ima visok nivo obrazovnog osujećenja i mišljenja smo da ovo nije ili ne bi trebao biti zanemarljiv procenat. Rezultati istraživanja pokazuju da postoji statistički značajna povezanost indeksa obrazovnog osujećenja sa godinama starosti, nivoom obrazovanja i profesijom. Dakle, rezultati poduzetog istraživanja koje smo prethodno sumirali pokazuju da je naša polazna pretpostavka da neka socijalno-demografska obilježja determinišu barijere obrazovanja i indeks obrazovnog osujećenja odraslih vjerovatna.

Kako smo već prethodno istakli, participacija odraslih u programima obrazovanja je vrlo kompleksan proces. Ukoliko neko društvo želi da postane društvo koje uči, koje svoju ekonomiju temelji i razvija na znanju, nužno se mora baviti barijerama obrazovanja odraslih. Dakle, najprije se mora raditi na identifikovanju ključnih barijera a onda sistematski pristupiti njihovom otklanjanju. Smatramo da se moraju perduzeti sve potrebne mjere kako bi se povećao broj pojedinaca koji participiraju u obrazovnim aktivnostima, a svakako se to najlakše može postići upravo identifikacijom i otklanjanjem faktora koji negativno utiču na sam proces obrazovanja odraslih. Ističemo da u našem društvu obrazovanje odraslih mora biti prepoznato kao važna karika cjelokupnog obrazovnog sistema jer je ono ključna komponenta i najočiglednija manifestacija doživotnog učenja, dakle ključni pokazatelj da li idemo putem društva koje uči.

\section{BARRIERS TO PARTICIPATION IN ADULT EDUCATION IN MONTENEGRO ${ }^{6}$}

\section{- Abstract -}

In a modern world, learning and education define the way of man's survival as well as social and individual development. We've been witnesses of everyday's growth of the educational needs of each individual, i.e. that the employment, the progress in one's profession, the change or keeping a workplace require induction into the learning and education process. It has

6 Excerpt from master's thesis. 
been known to us that the process of participation of adults into the education programmes is followed by various impediments, and the result of that is extremely low rate of participation in Montenegro, as well as in the other countries of the region. Therefore, this paper is directed towards perceiving the key impediments in the education of adults, in fact, the goal of the research was actually about establishing the impediments hierarchy and establishing a connection between a set of social-demographic characteristics and the educational impediments, as well as the level of educational disruption.

Key words: education of adults, educational impediments, participation.

\section{Literatura}

- Despotović, M. (2000): Igra potreba, Institut za pedagogiju i andragogiju Filozofskog fakulteta u Beogradu, Andragoško društvo Srbije, Beograd.

- Đukanović, R. (2008): Andragogija, Zavod za udžbenike i nastavna sredstva Podgorica, Podgorica.

- Komisija Evropske Zajednice, Komunikacija komisije, Obrazovanje odraslih: Nikad nije kasno za učenje, Brisel, 2006. (u časopisu: Andragoške studije, br. 2, (2007.), Institut za pedagogiju i andragogiju Beograd).

- Kulić, R. (1997): Sadržaj rada i obrazovanje, Institut za pedagogiju i andragogiju Filozofskog fakulteta u Beogradu, Beograd.

- Kulić, R., Despotović, M. (2005): Uvod u andragogiju, Svet knjige, Beograd.

- Rogers, A. (2003): Teaching Adults, Open University Press, Philadelphia.

- Savićević, D. (1989): Koncepcija obrazovnih potreba, Zavod za udžbenike i nastavna sredstva Beograd, Institut za pedagoška istraživanja Beograd, Katedra za Andragogiju Filozofskog fakulteta Beograd, Beograd.

- Savićević, D. (1991): Savremena shvatanja andragogije, Institut za pedagogiju i andragogiju Filozofskog fakulteta, Beograd.

- Savićević, D. (2000): Put ka društvu učenja, DP Đuro Salaj, JNIP Prosvetni pregled Beograd, Beograd.

- Savićević, D. (2011): Uvod u metodologiju andragogije, Visoka škola strukovnih studija za obrazovanje vaspitača „Mihailo Pavlov,” Vršac. 
- Tuijnman, A. Ed. (1996): International encyclopedia of adult education and training, „Pergamon,„, Oxford.

- Web izvori:

- Malhotra, N., Sizoo, S., Chorvat, V. (1999): Barriers to adult participation in undergraduate education, ,Adult Higer Education Alliance,

Dostupno na:

- www.ahea.org/files/pro1999malhotra.pdf [20. 5. 2102.];

- www.monstat.org. Dostupno: [15. 6. 2012.];

- www.stat.fi/til/aku/1995. Dostupno: [19. 5. 2012.]. 